\title{
Can the Internal Locus of Control as a Moderating Variables on the Effect of Three Intelligence on Financial Accounting Understanding?
}

\author{
Sigit Hermawan $^{1 *}$, Vela Purwaningsih ${ }^{2}$ Nihlatul Qudus Sukma Nirwana ${ }^{3}$ \\ 1,2, 3 Muhammadiyah University of Sidoarjo \\ *Corresponding author. Email: Sigithermawan@umsida.ac.id
}

\begin{abstract}
This study aims to determine the effect of intellectual intelligence, emotional intelligence, and spiritual intelligence on the understanding of financial accounting with internal locus of control as a moderating variable. The sample of this study was 228 students of the Study Program in Accounting, Faculty of Business, Law and Social Sciences, Universitas Muhammadiyah Sidoarjo. The data collection method uses a questionnaire. Data analysis method used is descriptive analysis. Testing data in this study using Partial Least Square (PLS) with the help of SmartPLS version 3.2.7. This study uses a validity test (convergent validity test and discriminant validity test) and reliability to determine data quality (Outer Model). And the hypothesis test (Inner Model) of this study is the Determinant Coefficient (R Square) and Analysis of Significance Testing (Path Coefisients). The results of this study indicate that intellectual intelligence has no effect on the understanding of financial accounting. Emotional intelligence and spiritual intelligence affect the understanding of financial accounting. Meanwhile, internal locus of control is not able to moderate the influence of intellectual and spiritual intelligence on the understanding of financial accounting. However, internal locus of control is able to moderate the influence of emotional intelligence on the understanding of financial accounting.
\end{abstract}

Keywords: Intellectual Intelligence, Emotional Intelligence, Spiritual Intelligence, Internal Locus of Control, Financial Accounting Understanding

\section{INTRODUCTION}

Education is the main basis for nation-building and is a process in producing quality future generations of the nation. Likewise, education in Indonesia, which has changed over time, really needs the attention of many parties such as the government, society and parents. Therefore education is very important, this is in accordance with the goal of the state, namely the intellectual life of the nation which has been regulated in Law Number 20 of 2003 concerning the national education system. Higher education is the highest level of education in the national education system and it is hoped that it will be able to produce competent and intellectual graduate students so that they can make a better and more advanced future for the Indonesian nation. Accounting education in tertiary institutions is education that educates students to be able to work as competent accountants in their fields, for this it needs to be improved in the education system. Understanding of accounting is very important, especially for students of the accounting study program, which has become the focus of the majors that have been taken since they started college.

In practice, not many accounting students have a clear goal orientation. Because they tend to be more confused about their reasons and goals for choosing an accounting program. Things like this can certainly have a bad impact on student learning outcomes or student performance to be unfocused and not in accordance with the goals of Indonesian education [1]. Accounting is divided into several groups, one of which is financial accounting. In general, the level of someone's good understanding of a science, including understanding financial 
accounting, can be influenced by several factors, where these factors can increase a person's understanding, such as the intelligence possessed by each individual.

There are several intelligences that can affect the understanding of financial accounting, including intellectual intelligence, emotional intelligence and spiritual intelligence. Intellectual intelligence must be balanced with emotional intelligence and spiritual intelligence because if it is only supported by intellectual intelligence, it does not mean that it can be successful in carrying out a job. According to [2], intellectual intelligence is the ability needed to do various mental activities to think, reason and solve problems. In previous research, several results were found, namely, research [2] which states that intellectual intelligence affects accounting understanding. However, these results are different from the research of [3] which states that intellectual intelligence has no and insignificant effect on accounting understanding.

On the other hand, the factors that are thought to affect the understanding of financial accounting are emotional intelligence and spiritual intelligence. According to [4], emotional intelligence is the intelligence to use emotions according to ability, the desire to control emotions so that it has a good impact. In previous research, several results were found, namely research [2] which states that emotional intelligence affects accounting understanding. However, the results of this study are different from [5] research which states that emotional intelligence affects understanding of basic accounting, and the next result is that emotional intelligence does not affect understanding of basic accounting with confidence as a moderating variable.

The next factor, namely spiritual intelligence, according to [6] is the ability to give meaning to worship for every behavior and activity carried out through steps and thoughts that are natural in nature, towards human beings who are whole and have integralistic thinking patterns, and have only principles. because Allah. In previous research, several results were found, namely, research [7] which states that spiritual intelligence has a positive effect on the level of accounting understanding. However, the results of this study are different from [8] study which states that spiritual intelligence has no effect on accounting understanding.

In addition there are other factors that can affect the level of understanding of student financial accounting, namely internal locus of control, which means the belief that everything happens comes from within that person. This study includes a moderating variable, namely internal locus of control on the influence of intellectual, emotional and spiritual intelligence on understanding financial accounting. This is supported by previous research, namely. research conducted by [9] which states that internal locus of control is able to moderate the effect of lecturer competence on student accounting understanding. However, this study is different from the research of [7], [10] and [11]. These studies use the internal locus of control variable not as a moderating variable on the effect of intellectual, emotional and spiritual intelligence on understanding financial accounting. Thus, the novelty of this study is the existence of a moderating variable internal locus of control on the influence of intellectual, emotional and spiritual intelligence on understanding financial accounting. Based on the explanation above, the formulation of the problems raised in this study are:

a) Does Intellectual Intelligence Affect the Students' Financial Accounting Understanding of the University of Muhammadiyah Sidoarjo?

b) Does Emotional Intelligence Affect the Students' Financial Accounting Understanding of the University of Muhammadiyah Sidoarjo?

c) Does Spiritual Intelligence Affect Students' Financial Accounting Understanding of the University of Muhammadiyah Sidoarjo?

d) Does Intellectual Intelligence Affect the Understanding of Financial Accounting in Muhammadiyah University Students in Sidoarjo with Internal Locus Of Control as a Moderating Variable?

e) Does Emotional Intelligence Affect the Understanding of Financial Accounting in Muhammadiyah University Students in Sidoarjo with Internal Locus of Control as a Moderating Variable?

f) Does Spiritual Intelligence Affect the Understanding of Financial Accounting in Muhammadiyah University Students in Sidoarjo with Internal Locus Of Control as a Moderating Variable?

Based on the formulation of the problem above, the objectives of this research are:

a. To Analyze the Effect of Intellectual Intelligence on Students' Financial Accounting Understanding of the University of Muhammadiyah Sidoarjo.

b. To Analyze the Effect of Emotional Intelligence on Students' Financial Accounting 
Understanding of the University of Muhammadiyah Sidoarjo.

c. To Analyze the Effect of Spiritual Intelligence on Students' Financial Accounting Understanding of the University of Muhammadiyah Sidoarjo.

d. To analyze the influence of intellectual intelligence on students' understanding of financial accounting at the Muhammadiyah University of Sidoarjo with internal locus of control as a moderating variable.

e. To Analyze the Effect of Emotional Intelligence on Students' Financial Accounting Understanding of the Muhammadiyah University of Sidoarjo with Internal Locus of Control as a Moderating Variable.

f. To analyze the influence of spiritual intelligence on students' understanding of financial accounting at the Muhammadiyah University of Sidoarjo with internal locus of control as a moderating variable.

\section{LITERATURE REVIEW}

\subsection{Multiple Intelligence Theory}

The theory of multiple intelligences is the ultimate validation of the idea that individual differences matter. Its use in education is very dependent on the recognition, recognition and appreciation of each individual, besides that the multiple intelligence theory not only recognizes these individual differences for practical purposes, such as teaching and assessment, but also considers and accepts them as normal, natural, even interesting and very valuable [12]. There are 8 multiple intelligences including the following: language intelligence, mathematical intelligence, visual space intelligence, physical movement intelligence, musical intelligence, interpersonal intelligence, intrapersonal intelligence, and environmental / natural intelligence.

\subsection{Attribution Theory}

Attribution theory is a process of how a person interprets an event, reason or cause of behavior. This theory was developed by [13] who argues that a person's behavior is determined by a combination of internal strength, namely factors that come from within a person such as ability or effort and external strength, namely factors that come from outside, such as difficulties. duty or luck.

1. Intellectual Intelligence

In everyday life, people think using their minds. Fast or not or whether a problem is resolved or not depends on the ability of intelligence they have [2].

2. Emotional Intelligence

According to [14] states that emotional intelligence (Emotional Intelligence) is a useful use of emotions by using it as a guide for behavior so that one's thoughts increase.

3. Spiritual Intelligence

According to [15] spiritual intelligence is the intelligence that has existed in every human being from birth which makes humans live life to the fullest. Meaning, always listening to the voice of his conscience, never feeling in vain, everything he does is always valuable.

4. Locus Of Internal Control

Internal Locus of Control is the ability of an individual's center that can help individuals to achieve better academic success [9].

5. Understanding of Financial Accounting

According to [16] a student's level of accounting understanding is expressed by how much a student understands what he has learned, in this context it refers to financial accounting courses. The sign that a student understands accounting is not only shown from the grades he gets or the achievements he has achieved in the form of a Grade Point Average (GPA), but if the student also understands and can master the related concepts. In addition, accounting education should at least be able to prepare students to start and develop a diversity of professional careers in the field of Accounting.

6. Conceptual Framework

The following can be described the conceptual framework of this research as follows:

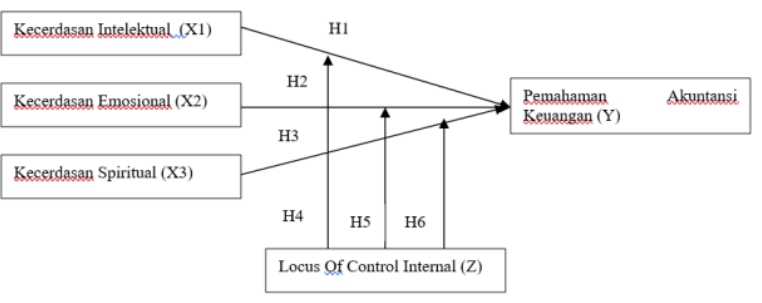

Figure 1. Conceptual Framework

7. Hypothesis Development

a. The Effect of Intellectual Intelligence on Understanding Financial Accounting Intellectual intelligence is closely related to understanding financial accounting. 
Intellectual intelligence is very necessary in understanding financial accounting because students who have intelligence in solving problems will increase their understanding of accounting. This is supported by research from [2] whose results are that intellectual intelligence has an effect on accounting understanding. Therefore, an accounting student who has good intellectual intelligence can also improve students' accounting understanding. So from the description above, the following hypothesis can be drawn:

H1. Intellectual intelligence affects the understanding of financial accounting.

b. The Effect of Emotional Intelligence on Understanding of Financial Accounting

Emotional intelligence is closely related to understanding financial accounting. Emotional intelligence is indispensable in understanding financial accounting, because students who are able to recognize their own emotions and respect the emotions of themselves and others can help optimize their understanding of financial accounting. This is supported by research from [11], the result is that emotional intelligence has a positive effect on the level of accounting understanding.

Therefore, an accounting student who has good emotional intelligence can also improve students' accounting understanding. This is also because emotional intelligence requires you to respect and demand your own feelings and the feelings of others. So from the description above, the following hypothesis can be drawn:

H2. Emotional intelligence affects the understanding of financial accounting.

c. The Effect of Spiritual Intelligence on Understanding Financial Accounting

Spiritual intelligence is closely related to understanding financial accounting. Spiritual intelligence is needed in understanding financial accounting, this means that someone who has good spiritual intelligence will increase his understanding of financial accounting. Because spiritual intelligence is the ability that humans have in interpreting the meaning of life more broadly, it will make humans able to position themselves and be able to respond to life's problems more positively, such as wiser and always trying in the process of understanding accounting. This is supported by research from [3], the result is that spiritual intelligence has an effect on accounting understanding.

Therefore, an accounting student who has good spiritual intelligence can also improve student accounting understanding. This is because students who have high spiritual intelligence will be able to calmly solve problems in studying accounting. So from the description above, the following hypothesis can be drawn:

H3. Spiritual intelligence affects the understanding of financial accounting

d. The Influence of Intellectual Intelligence on the Understanding of Financial Accounting with Internal Locus of Control as a Moderating Variable

Intellectual intelligence is closely related to Internal Locus Of Control and understanding of financial accounting. Of these two things (intellectual intelligence and internal locus of control) are very necessary in understanding financial accounting, because students who have good intellectual intelligence and show a higher learning enthusiasm and independence will be able to control themselves and their surroundings so that it will have an impact. good for understanding financial accounting. This is supported by research from [2] whose results are that intellectual intelligence has an effect on accounting understanding. According to [7], the results of which internal locus of control have a positive and significant effect on accounting understanding and also [9] research which results are that internal locus of control is able to moderate the relationship between Lecturer Competence and the Level of Accounting Comprehension.

Therefore, an accounting student who has a good internal locus of control will increase his intellectual intelligence and will make it easier to understand financial accounting. So from the description above, the following hypothesis can be drawn:

H4. Intellectual intelligence affects the understanding of financial accounting with internal locus of control as a moderating variable.

e. The Effect of Emotional Intelligence on the Understanding of Financial Accounting with 
Internal Locus of Control as a Moderating Variable

Emotional intelligence is closely related to Internal Locus Of Control and understanding of financial accounting. Of these two things (Emotional Intelligence and Internal Locus Of Control) are indispensable in understanding financial accounting, because students who have good emotional intelligence and internal locus of control such as being able to control themselves, have the motivation to keep trying, not easily give up, are able cope with stress and believe that everything / events that occur in his life is a control over himself, it will have a good impact on understanding financial accounting. In addition, students who do not rely less on their intellectual intelligence, they usually try with their shortcomings to rely on other intelligences, namely emotional intelligence, such as being able to relate well to other people, be it with friends or lecturers. This is supported by research from [8], the result is that emotional intelligence has an effect on accounting understanding. According to [7], the results of which internal locus of control have a positive and significant effect on accounting understanding and also [9] research which results are that internal locus of control is able to moderate the relationship between Lecturer Competence and the Level of Accounting Comprehension. Therefore, an accounting student who has a good internal locus of control will increase his emotional intelligence and will make it easier to understand financial accounting. So from the description above, the following hypothesis can be drawn:

H5. Emotional intelligence affects the understanding of financial accounting with internal locus of control as a moderating variable.

f. The Effect of Spiritual Intelligence on the Understanding of Financial Accounting with Internal Locus of Control as a Moderating Variable

Spiritual intelligence is closely related to Internal Locus Of Control and understanding of financial accounting. Of these two things (spiritual intelligence and internal locus of control) are indispensable in understanding financial accounting, because students who have good self-control are able to overcome various problems faced in accounting problems such as not easy to give up in trying. In addition, students have good spiritual intelligence, they will quickly be motivated in learning and easy to concentrate so that it will be easy to understand a course, especially in understanding financial accounting, because students who ignore their spiritual intelligence are only pursuing achievements in the form of values or numbers. so that it will justify any means to get good grades and will tend to commit fraudulent or dishonest acts such as cheating on exams. Therefore spiritual intelligence will greatly assist students in achieving success. This is supported by research from [17], the result is that spiritual intelligence has an effect on accounting understanding. According to [11] internal locus of control has a positive influence on the level of accounting understanding and also [9] research which results is that internal locus of control is able to moderate the relationship between Lecturer Competence and the Level of Accounting Comprehension. Therefore, an accounting student who has a good internal locus of control will increase his spiritual intelligence and will make it easier to understand financial accounting. So from the description above, the following hypothesis can be drawn:

H6. Spiritual intelligence affects the understanding of financial accounting with internal locus of control as a moderating variable.

\section{RESEARCH METHOD}

The approach in this research uses a quantitative approach [18]. Because this study examines the effect of intellectual intelligence, emotional intelligence, and spiritual intelligence on understanding financial accounting with internal locus of control as a moderating variable. According to [22] population is a generalization area consisting of subjects / objects that have certain characteristics selected by researchers to be used in research. The population in this study were all students majoring in accounting at Muhammadiyah University Sidoarjo, totaling 1144 students. 
The sample in this study was selected using a purposive sampling method, with the criteria for determining the sample as follows:

a. S1 student majoring in accounting, class 2016 who is still active and has a GPA> 3.00

b. Students who have passed Introductory Accounting 1, Introductory Accounting 2, Intermediate Financial Accounting 1, Intermediate Financial Accounting 2, Advanced Financial Accounting 1 and Advanced Financial Accounting 2 because researchers think these students have benefited from learning financial accounting and can gain an understanding of accounting. Based on the above criteria, after making observations, the total sample size is 228 students.

The data collected in this study are primary data. Primary data can be obtained by using a question (questionnaire) method. This study uses descriptive statistical data analysis where descriptive statistics in this study are statistics used to analyze data by describing or describing the data that has been collected as it is without intending to make generalized conclusions or generalizations [22]

In this study, analysis and testing tools were used to test hypotheses related to the relationship among research variables using the SmartPLS program.

a. Partial Least Square (PLS)

1) This study uses the Partial Least Squares (PLS) method which is used to analyze the data and test the proposed hypothesis. In PLS there are two stages of evaluation, the first is evaluation of Measurement Model (Outer Model), the evaluation of this measurement model consists of validity tests, namely convergent validity and discriminant validity and reliability testing using two methods, namely Cronbach's negligence and composite reliability. The second is evaluation of the structural model / hypothesis testing with the prediction model (Inner Model) The test is carried out using the value of $\mathrm{R}$ Square $\left(\mathrm{R}^{2}\right)$ and the path coefficient.
There are five variables measured in this research. The indicators as follows:

a. Intellectual intelligence (X1) According to [19] intellectual intelligence is the ability to think and reason which is needed to carry out various activities and to solve problems.

b. Emotional Intelligence (X2)

According to [20] Emotional intelligence does not only function to control oneself, but also the ability to manage ideas, concepts, so that it becomes an interest for many people. A person who has a good level of emotional intelligence can become a person who is quicker to calm himself down, is faster in focusing his attention, is easier to get along with people and works in the field for the better.

c. Spiritual Intelligence (X3)

According to [2] Spiritual intelligence is a form of foundation in building intellectual intelligence and spiritual intelligence. A person who has a higher level of spiritual intelligence is able to give meaning to life by giving a good meaning to every event, problem, even suffering he experiences. Therefore, giving good meaning will be able to awaken the soul and do positive actions and actions.

d. Understanding of financial accounting (Y) According to [16] a student's level of accounting understanding is expressed by how much a student understands what he has learned, in this context it refers to financial accounting courses. The sign that a student understands accounting is not only shown from the grades he or she has achieved in the form of a Grade Point Average (GPA), but also if the student understands and can master the concepts related to Internal.

e. Locus Of Control (Z)

According to [21], internal locus of control is someone who believes that they are in control of what happens to themselves. 
From the variable definition, it can be explained that the variable indicators listed in the hypothesis to be tested in this study are as follows:

Table 1. Variable Indicators

\begin{tabular}{|l|l|l|l|}
\hline Variable & Indicator & Scale & Sources \\
\hline $\begin{array}{l}\text { Intelligence } \\
\text { Intellectual (X1) }\end{array}$ & $\begin{array}{l}\text { Breaking ability } \\
\text { problem } \\
\text { Verbal Intelligence } \\
\text { Practical Intelligence }\end{array}$ & $\begin{array}{l}\text { Measured through } \\
\text { Likert scale 1-5 } \\
\text { points }\end{array}$ & [2]; [7] \\
\hline $\begin{array}{l}\text { Intelligence } \\
\text { Emotional (X2) }\end{array}$ & $\begin{array}{l}\text { Introduction } \\
\text { self-control } \\
\text { motivation } \\
\text { empathy } \\
\text { social skills }\end{array}$ & $\begin{array}{l}\text { Measured through } \\
\text { Likert scale 1-5 } \\
\text { points }\end{array}$ & [17]; [8]; [5] \\
\hline $\begin{array}{l}\text { Spiritual } \\
\text { Intelligence }\end{array}$ & $\begin{array}{l}\text { self-awareness ability to face and } \\
\text { take advantage of suffering } \\
\text { ability to face and go beyond pain } \\
\text { reluctance to causing its losses no } \\
\text { need quality of life } \\
\text { holistic view inclination to ask } \\
\text { independent field }\end{array}$ & $\begin{array}{l}\text { Likert scale 1-5 } \\
\text { points }\end{array}$ & [7]; [2]; [8];[17] \\
\hline $\begin{array}{l}\text { Locus Of Control } \\
\text { Internal (Z) }\end{array}$ & $\begin{array}{l}\text { Ability Skills / abilities } \\
\text { (Skill) Effort (Effort) }\end{array}$ & $\begin{array}{l}\text { Measured through } \\
\text { Likert scale } \\
\text { points }\end{array}$ & [21] \\
\hline $\begin{array}{l}\text { Understanding } \\
\text { Financial } \\
\text { Accounting }\end{array}$ & $\begin{array}{l}\text { Understanding of the concepts } \\
\text { introduction of accounting } \\
\text { Understanding of the concepts } \\
\text { financial Accounting medium } \\
\text { Understanding of the concepts } \\
\text { advanced financial accounting }\end{array}$ & $\begin{array}{l}\text { Measured through } \\
\text { pikert scale 1-5 }\end{array}$ & [16] \\
\hline
\end{tabular}

\section{RESULTS AND DISCUSSION}

Based on the questionnaire data obtained, the researchers tested the quality of the data in the form of validity tests and data reliability tests.

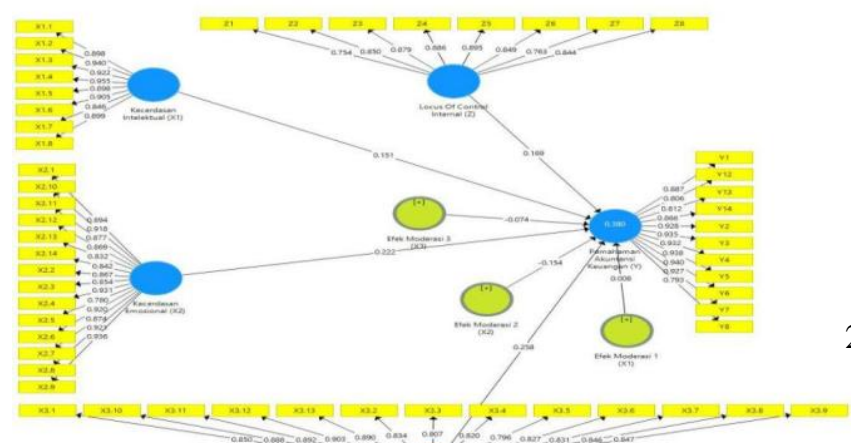

Figure 2. PLS output
1. Validity test

All variables in this study are declared to meet convergent validity because it can be seen that all the questions in the questionnaire have a loading value above 0.7 . In addition, it also fulfills discriminant validity because the loading value of each statement item (to the measured variable / construct) is greater than the loading value of other variables / constructs. Therefore, each of the statement items mentioned above is valid for measuring the appropriate variable / construct.

2. Reliability Test

In this study, researchers used two methods in measuring the level of reliability of each statement item contained in the instrument, namely Cronbach's alpha and composite reliability. 
Measurement items in this study are said to be reliable because they have an alpha coefficient and composite reliability above 0.7 .

3. Hypothesis Testing
After testing the validity and reliability, the hypothesis is tested. The test is done by looking at the value of $R$ Square $\left(R^{2}\right)$ and the significance of the path relationship (looking at the $\mathrm{P}$ value).

Table 2. R Square

\begin{tabular}{||c|c|}
\hline Variable & R Square \\
\hline Understanding of Financial Accounting (Y) & 0.380 \\
\hline
\end{tabular}

Based on the results from table 2 above, the $\mathrm{R}$ Square value for the variable understanding of financial accounting (Y) shows a value of 0.380 . This means that the variables of intellectual intelligence, emotional intelligence, spiritual intelligence and internal locus of control can explain the diversity of variables in understanding financial accounting by $38 \%$, while the remaining $62 \%$ is explained by the contribution of other variables not discussed in this study, such as learning behavior, motivation., and others.

Table 3. Path Coefficient

\begin{tabular}{|l|c|c|c|c|c|}
\hline & $\begin{array}{l}\text { Sample } \\
\text { Asli (O) }\end{array}$ & $\begin{array}{l}\text { Sample } \\
\text { Mean (M) }\end{array}$ & $\begin{array}{l}\text { Standar } \\
\text { Deviasi } \\
\text { (STDEV) }\end{array}$ & $\begin{array}{l}\text { T Statistik (| } \\
\text { O/STDEV|) }\end{array}$ & P Values \\
\hline $\begin{array}{l}\text { Moderation Effect 1 (X1) } \\
\text { >Accounting Understanding } \\
\text { Finance (Y) }\end{array}$ & 0.008 & 0.004 & 0.070 & 0.112 & 0.911 \\
\hline $\begin{array}{l}\text { Moderation Effect 2 (X2) -> } \\
\text { Accounting Understanding } \\
\text { Finance (Y) }\end{array}$ & -0.154 & -0.163 & 0.070 & 2.208 & 0.029 \\
\hline $\begin{array}{l}\text { Moderation Effect 3 (X3) -> } \\
\text { Accounting Understanding } \\
\text { Finance (Y) }\end{array}$ & -0.074 & -0.061 & 0.084 & 0.882 & 0.379 \\
\hline $\begin{array}{l}\text { Emotional Intelligence (X2) - } \\
\text { > Accounting Understanding } \\
\text { Finance (Y) }\end{array}$ & 0.222 & 0.224 & 0.069 & 3.225 & 0.002 \\
\hline $\begin{array}{l}\text { Intellectual Intelligence } \\
\text { (X1) -> Understanding } \\
\text { Financial Accounting (Y) }\end{array}$ & 0.151 & 0.169 & 0.078 & 1.945 & 0.053 \\
\hline $\begin{array}{l}\text { Spiritual Intelligence } \\
\text { (X3) -> Understanding } \\
\text { Financial Accounting (Y) }\end{array}$ & 0.258 & 0.238 & 0.073 & 3.541 & 0.001 \\
\hline $\begin{array}{l}\text { Locus Of Control } \\
\text { Internal (Z) -> } \\
\text { Accounting Understanding } \\
\text { Finance (Y) }\end{array}$ & 0.169 & 0.180 & 0.065 & 2.607 & 0.010 \\
\hline
\end{tabular}




\section{DISCUSSION}

a. The influence of intellectual intelligence on understanding financial accounting

The results of table 3 explain that intellectual intelligence on the understanding of financial accounting shows that the $\mathrm{t}$ statistic value is 1.945 , which is smaller than 1.96 , and a p-value of 0.053 is greater than 0.05 , this means that intellectual intelligence has no effect on understanding financial accounting. The results of this study support the research conducted by [3] which states that intellectual intelligence has no effect on understanding financial accounting. However, the results of this study are different from research by [2], [8], [23], and [7] which state that intellectual intelligence has an effect on understanding financial accounting.

This shows that many students do not use their intellectual intelligence in understanding financial accounting, such as a lack of knowledge and curiosity about things that are not yet known. That way, intellectual intelligence that is owned cannot affect the mindset of a student in understanding financial accounting. In addition, the Umsida students who were the respondents of this study were morning and night students who were classified as mostly undergoing lectures as workers, especially for night students who indeed almost all consisted of students who were already working. These student worker profiles are known to have stronger motivation than others, have good communication skills, have energy and can manage emotions well. The point is that night students are more likely to have good personal and social skills because they have more experience when these students work. This explains that night students are lacking intellectually, because they are also influenced by various factors such as lack of concentration when the lecturer explains in class, easily feels tired and sleepy so that it will split their concentration and will affect their intellectual and will be difficult in understanding financial accounting. b. The effect of emotional intelligence on understanding financial accounting

The results of table 3 explain that emotional intelligence on understanding financial accounting shows a t-statistic value of 3,225 is greater than 1.96, and a p-value of 0.002 is smaller than 0.05 , this means that emotional intelligence has an effect on understanding financial accounting.

The results of this study support research conducted by [2], [8], [7], [10], [11], and [24] which state that emotional intelligence affect the understanding of accounting in addition to the better application of emotional intelligence students have, their understanding of financial accounting will also increase. However, the results of this study are different from the research of [5] which states that emotional intelligence has no effect on accounting understanding.

This shows that emotional intelligence requires learning to acknowledge and appreciate the feelings of oneself and others and apply it in daily life and work. Thus the emotional intelligence factor which is measured through self-introduction, self-control, motivation, empathy, and social skills is a factor that will affect accounting understanding.

c. The influence of spiritual intelligence on understanding financial accounting

The results of table 3 explain that spiritual intelligence on the understanding of financial accounting shows a t-statistic value of 3.541 is greater than 1.96 , and a p-value of 0.001 is smaller than 0.05 , this means that spiritual intelligence has an effect on understanding financial accounting..

The results of this study support research conducted by [7], [2], [17] and [3] which state that spiritual intelligence affects the level of accounting understanding. However, the results of this study are different from [8] study which states that spiritual intelligence has no effect on the level of accounting understanding.

This shows that most students always learn and apply spiritual values in everyday life such as always being patient, trying and never giving up when faced with various 
difficulties such as understanding financial accounting. In addition, it also indicates that students are able to place themselves and live more positively with wisdom and peace in every respect. In practice, Umsida accounting students have also been equipped with religion-based courses that will support their spiritual intelligence. It is hoped that accounting students can have more spiritual intelligence than other campus students.

d. The influence of intellectual intelligence on understanding financial accounting with internal locus of control as a moderating variable

The results of table 3 explain that the moderation effect of $\mathrm{X} 1$ on the understanding of financial accounting has a statistical t value of 0.112 which is smaller than 1.96 and a pvalue of 0.911 is greater than 0.05 , so it can be stated that internal locus of control is unable to moderate the effect of intellectual intelligence on understanding financial accounting. .

The results of this study do not support the research conducted by [9] which states that the internal locus of control is able to moderate the effect of lecturer competence on student accounting understanding. However, the results of this study are different from those of [25], [10] and [11]. These studies use the internal locus of control variable not as a moderating variable on the effect of intellectual, emotional and spiritual intelligence on understanding financial accounting.

This shows that the Umsida students who were the respondents of this study were morning and night students who were classified as mostly undergoing lectures as workers, especially for night students who indeed almost all consist of students who are already working. These student worker profiles are known to have stronger motivation than others, have good communication skills, have energy and can manage emotions well. The point is that night students are more likely to have good personal and social skills because they have more experience when these students work. This explains that night students are lacking intellectually, because they are also influenced by various factors such as lack of concentration when the lecturer explains in class, easily feels tired and sleepy so that it will split their concentration and will affect their intellectual and will be difficult in understanding financial accounting. In addition, the addition of the moderating variable in this study, namely internal locus of control, proves that it cannot make students more confident about everything that happens in their life that it originates within itself, most likely especially for night students they tend to have more external locus of control. . So that they feel that an achievement depends on the surrounding environment and this is what makes their intellectual low, which will then have an impact on their understanding of financial accounting.

e. The effect of emotional intelligence on understanding financial accounting with internal locus of control as a moderating variable

The results of table 3 explain that the moderating effect of $\mathrm{X} 2$ on the understanding of financial accounting has a statistical $t$ value of 2.208 which is greater than 1.96 and a pvalue of 0.029 which is smaller than 0.05 , so it can be stated that internal locus of control is able to moderate the effect of emotional intelligence on understanding financial accounting.

The results of this study support the research conducted by [9] which states that the internal locus of control is able to moderate the effect of lecturer competence on student accounting understanding.

This shows that students with good internal locus of control will make students' emotional skills increase and have the motivation to excel, then it will have a good effect on their understanding of financial accounting.

f. The influence of spiritual intelligence on understanding financial accounting with internal locus of control as a moderating variable

The results of table 3 explain that the moderation effect of X3 on understanding financial accounting has a statistical $t$ value of 
0.882 smaller than 1.96 and a p-value of 0.379 greater than 0.05 , it can be stated that internal locus of control is unable to moderate the effect of spiritual intelligence on understanding financial accounting.

The results of this study do not support the research conducted by [9] which states that the internal locus of control is able to moderate the influence lecturer competence on student accounting understanding. However, the results of this study are different from those of [25], [10] and [11]. These studies use the internal locus of control variable not as a moderating variable on the effect of intellectual, emotional and spiritual intelligence on understanding financial accounting.

Students who have spiritual intelligence will be able to interpret everything they do as a form of worship and will be able to control themselves not to do negative things. This shows that accounting students who do not have good spiritual intelligence will find it difficult to fulfill a high sense of responsibility for everything they do so that it will be difficult to understand financial accounting. In addition, accounting students have also been provided with religious courses and other softkills-based courses that support spiritual intelligence. In practice, the existence of an internal locus of control variable in this study did not make students more confident, responsible and did not commit prohibited or negative actions, because they were more likely to have external locus of control. So that it will make his spiritual level low and difficult to understand financial accounting.

\section{CONCLUSIONS}

a. Intellectual intelligence has no effect on understanding financial accounting. This means that many students do not use their intellectual intelligence in understanding financial accounting, such as a lack of knowledge and curiosity about unknown things.

b. Emotional intelligence affects the understanding of financial accounting. This means that with the better application of emotional intelligence students have, their understanding of financial accounting will also increase.

c. Spiritual intelligence affects the understanding of financial accounting. This means that the better the application of spiritual intelligence that students have, their understanding of financial accounting will also increase.

d. Intellectual intelligence has no effect on understanding financial accounting with internal locus of control as a moderating variable. This means that internal locus of control is not able to moderate the effect of intellectual intelligence on understanding financial accounting.

e. Emotional intelligence affects the understanding of financial accounting with internal locus of control as a moderating variable. This means that internal locus of control is able to moderate the effect of emotional intelligence on understanding financial accounting.

f. Spiritual intelligence has no effect on understanding financial accounting with internal locus of control as a moderating variable. This means that internal locus of control is not able to moderate the influence of spiritual intelligence on understanding financial accounting.

Based on the results of existing research, the researcher can provide the following suggestions,

for further researchers, it is hoped that they can add other independent variables or intervening variables that can affect the understanding of financial accounting and can expand the object of research by researching more than one university.

Further researchers are also expected to use more samples and add data collection techniques, not only through distributing questionnaires but also by conducting direct interviews to obtain more accurate results.

a. Accounting students are expected to improve their intellectual intelligence, emotional intelligence, spiritual intelligence and internal locus of control so that they can motivate themselves to study hard in order to improve 
their understanding of financial accounting and when they graduate from college, they are reliable and ready to work with expertise in accounting.

In this study, there are several limitations that need to be considered for the perfection of further studies. The object of this research is limited to accounting students at 1 private university in Sidoarjo, namely the University of Muhammadiyah Sidoarjo. The data collection technique in this study was carried out by distributing questionnaires, which means that the reliability of the research data depends on the objectivity and honesty of the answers of accounting respondents / students who are used as research samples. In addition, due to limited time and research personnel, it also resulted in some questionnaires not being returned.

\section{REFERENCES}

[1] S. Biduri, "Pengaruh State Goal Orientation Terhadap Performance Dengan Self-Efficacy Sebagai Variabel Pemoderasi Aplikasi Mata Kuliah Akuntansi Keuangan Lanjutan II," J. Ekon. Manaj. Akunt., vol. 14, no. 1, pp. 3137, 2018.

[2] F. Zakiah, "Pengaruh Kecerdasan Intelektual, Kecerdasan Emosional, Kecerdasan Spiritual Terhadap Pemahaman Akuntansi. Jember: Skripsi. Fakultas Ekonomi, Universitas Jember.," 2013.

[3] H. Kurniansyah and N. Daveta, "The influence of intelligent intellectual, emotional, and spiritual on accounting understanding.," J. Off Bussiness., 2016.

[4] R. Melandy and N. Aziza, "Pengaruh Kecerdasan Emosional Terhadap Tingkat Pemahaman Akuntansi, Kepercayaan Diri sebagai Variabel Pemoderasi.," Simp. Nas. Akunt. 9, pp. 1-49, 2006.

[5] N. A. Ningsih and S. Hermawan, "Pengaruh Kecerdasan Intelektual,Kecerdasan Emosional, dan Perilaku Belajar Terhadap Pemahaman atas Akuntansi Dasar Mahasiswa Dengan Kepercayaan Diri Sebagai
Pemoderasi.," J. Account. Sci., vol. 3, no. 1, pp. 60-66, 2019.

[6] Dwi I, "Pengaruh Kecerdasan emosional, Kecerdasan Intelektual, Kecerdasan Spiritual Dan Kecerdasan Sosial Terhadap Tingkat Pemahaman Akuntansi Dengan Minat Sebagai Pemoderasi.," J. Akunt. dan Sist. Teknol. Inf., vol. 12, pp. 122-130, 2016.

[7] K. T. W. Saputra, "Pengaruh Kecerdasan Emosional, Kecerdasan Spiritual, dan Kecerdasan Intelektual Terhadap Tingkat Pemahaman Akuntansi. Yogyakarta: Skripsi. Fakultas Ekonomi, Universitas Negeri Yogyakarta.," 2018.

[8] F. Yani, "Pengaruh Kecerdasan Intelektual, Kecerdasan Emosional, dan Kecerdasan Spiritual Terhadap Pemahaman Akuntansi. .," J. Akunt. Pendidik., 2011.

[9] F. Harimurti and Rispantyo, "Internal Locus Of Control Sebagai Moderasi Pada Pengaruh Kompetensi Dosen Terhadap Tingkat Pemahaman Akuntansi.," J. Akunt. dan Sist. Teknol. Inf., vol. 10, no. 1, pp. 50-62, 2014.

[10]D. Primasari, "Pengaruh Kecerdasan Emosional, Tingkat Idealisme, Perilaku Belajar dan Locus Of Control Terhadap Tingkat Pemahaman Akuntansi Mahasiswa Strata (S-1) Akuntansi," J. Maksipreneur, vol. 6, no. 1, pp. 14-23, 2016.

[11]D. Widhiyani, "The influence of emotional quotient and internal locus of control on the level of accounting understanding.," Eur. J. Bussiness Manag., vol. 9, no. 9, pp. 86-92, 2017.

[12]R. Rudiantoro and S. V. Siregar, "Jurnal Akuntansi dan Keuangan Indonesia," vol. 9(1), pp. 1-21, 2012.

[13]I. W. Suartana, Akuntansi Keprilakuan. Yogyakarta: CV Andi Offset, 2010.

[14]H. Weisinger, Emosional Intelligence at Work: Pemandu Pikiran dan Perilaku Anda Untuk Meraih Kesuksesan. Jakarta: PT Bhuana Ilmu Populer., 2006.

[15]A. Wahab and Umiarso, Kepemimpinan pendidikan dan Kecerdasan Spiritual. Jogjakarta: Ar - Ruzz. 2011.

[16]A. A. Manansal, "Kecerdasan emosi mahasiswa akuntansi fakultas ekonomi dan bisnis pengaruhnya terhadap tingkat pemahaman akuntansi," J. Ris. Ekon. 
Manajemen, Bisnis dan Akunt., vol. 1, no. 3, 2013.

[17]F. Rachmi, "Pengaruh Kecerdasan Emosional, Kecerdasan Spiritual, dan Perilaku Belajar Terhadap Tingkat Pemahaman Akuntansi. Semarang: Skripsi. Fakultas Ekonomi, Universitas Diponegoro Semarang.," 2010.

[18] S. Hermawan and Amirullah, Metodologi Penelitian Bisnis. Malang: Media Nusa Creative. 2016.

[19]A. Y. Rohim, "Pengaruh Kecerdasan Emosional, Kecerdasan Intelektual, Kecerdasan Spiritual Terhadap Pengambilan Keputusan Etis Dengan Locus Of Control Sebagai Variabel Pemoderasi. Sidoarjo: Skripsi. Fakultas Ekonomi, Universitas Muhammadiyah Sidoarjo.," 2013.

[20]E. Mustafa, "Pengaruh Kecerdasan Intelektual dan Kecerdasan Emosional Berdasarkan Gender Terhadap Tingkat Pemahaman Akuntansi. Makassar: Skripsi. Fakultas Ekonomi dan Bismis Islam, UIN Alauddin Makassar.," 2014.

[21]D. S. Murni, "Hubungan Internal Locus Of Control Dengan Intensi Berwirausaha Pada Mahasiswa. Malang: Skripsi. Fakultas Psikologi, Universitas Muhammadiyah Malang.," 2017.

[22] Sugiyono, Metode Penelitian Bisnis. Bandung: Alfabeta, 2016.

[23] S. Hermawan and W. Nurlia, "Dapatkah Love Of Money Sebagai Variabel Intervening Pengaruh Kecerdasan Terhadap Persepsi Etis Mahasiswa Akuntansi. Jurnal Ilmiah Akuntansi dan Bisnis, 12(2), 93-103.," 2017.

[24] V. P. Chaer and O. Usman, "The effect of emotional intelligence, learning behavior, learning and interest on the level of understanding in accounting students faculty of economic state university of Jakarta. Journal Of Economics.," 2016.

[25]D. Putra, "Pengaruh Sifat Kepribadian Locus Of Control dan Self Efficacy pada Pemahaman Akuntansi. JAA, 3(2), 117-143.," 2019. 